Acta vet. scand. $1974,15,340-355$.

From the Department of Pharmacology and Toxicology, Royal Veterinary and Agricultural University, Copenhagen, Denmark.

\title{
MAMMARY AND RENAL EXCRETION OF SULPHADOXINE AND TRIMETHOPRIM IN COWS*
}

\author{
By \\ Danis Davitiyananda ${ }^{\star \star}$ and Folke Rasmussen
}

\begin{abstract}
DAVITIYANANDA, DANIS and FOLKE RASMUSSEN: Mammary and renal excretion of sulphadoxine and trimethoprim in cows. Acta vet. scand. 1974, 15, 340-355. - In 21 experiments on 5 healthy, nonpregnant cows are sulphadoxine and trimethoprim infused intravenously for maintenance of constant levels of the drugs through the experimental periods. The experiments show that both sulphadoxine and trimethoprim are bound to the proteins in blood plasma and milk. Further it is demonstrated that sulphadoxine (an acid) is excreted into milk in concentrations lower than in blood plasma while trimethoprim (a base) is excreted into milk in concentrations higher than in blood plasma. Both results are consistent with the theory that drugs are excreted through the mammary gland by passive diffusion.

Glomerular filtration and back-diffusion are both involved in the renal handling of sulphadoxine and trimethoprim. For trimethoprim active tubular secretion is also demonstrated. Both the mammary and renal handling of sulphadoxine as well as trimethoprim are influenced by the $\mathrm{pH}$ of milk and urine, respectively. The experiments underline that it is the unionized, non-protein-bound fraction of the drugs which diffuses through biological membranes.
\end{abstract}

sulphadoxine; trimethoprim; mammary excretion; renal excretion; cow.

In earlier publications it has been shown that only the nonprotein-bound and unionized fraction of weak electrolytes diffuses through the mammary gland epithelium. This means that acids are excreted into milk in concentrations equal to or lower than those in plasma, while bases are excreted into milk in con-

* Supported by the Danish Agricultural and Veterinary Research Council.

* On leave from the Department of Pharmacology, Veterinary Faculty, Bangkok, Thailand. 
centrations equal to or higher than those in plasma (Rasmussen 1958, 1959, 1966, 1971, 1973, Sisodia \& Stowe 1964, Stowe \& Plaa 1968, Ziv \& Risenberg-Tirer 1969, Ziv \& Sulman 1973 a, b). Further, it has been shown that the unionized fraction of chemotherapeutics in renal tubular fluid is responsible for the backdiffusion from tubular lumen to blood circulation (Beyer et al. 1944, Dalgaard-Mikkelsen 1951, Dalgaard-Mikkelsen \& Poulsen 1956, Sharpstone 1969, Rasmussen 1970, Jørgensen \& Rasmussen 1972). The ionization of the acid sulphadoxine and the base trimethoprim is changed in opposite directions when the $\mathrm{pH}$ in the medium is changed. These drugs are normally used in fixed combinations and it seemed, therefore, to be of interest to investigate the mammary and renal handling of simultaneously infused sulphadoxine and trimethoprim.

\section{EXPERIMENTAL}

Twenty-one experiments were conducted on 5 healthy, nonpregnant cows with individual milk yield varying from 3 to $8 \mathrm{~kg}$ per day. The kidneys and udders were clinically normal. In each experiment an initial intravenous infusion of sulphadoxine* (4-sulphanilamido-5,6-dimethoxy-pyrimidine) and/or trimethoprim $^{\star \star}$ (2,4-diamino-5-(3,4,5-trimethoxybenzyl)-pyrimidine) was given, and subsequently, the concentration in blood plasma was kept constant by continuous intravenous infusion of sulphadoxine through a plastic catheler (Intracath $\left.{ }^{\circledR}\right)$ placed in the left jugular vein and by infusion of trimethoprim through another plastic catheter in the same vein. The lowest and highest priming doses of sulphadoxine used were 7 and $55 \mathrm{mg} / \mathrm{kg} \mathrm{b.wt.} \mathrm{followed}$ by maintenance doses of 2 and $15 \mathrm{mg} / \mathrm{kg}$ b.wt. per hr., respectively. For trimethoprim the priming doses were 3 and $6 \mathrm{mg} / \mathrm{kg}$ b.wt. followed by maintenance doses of 0.7 and $1.6 \mathrm{mg} / \mathrm{kg}$ b.wt. per hr. The priming dose of sulphadoxine was dissolved in $75 \mathrm{ml}$ distilled water by adding $5 \mathrm{~N}-\mathrm{NaOH}(0.7-1 \mathrm{ml} 5 \mathrm{~N}-\mathrm{NaOH}$ per g sulphadoxine) and infused in $10 \mathrm{~min}$. The solutions of sulphadoxine used for the continuous intravenous infusion were prepared in the same way and diluted with $0.9 \%$ sodium chloride solution. The priming dose of trimethoprim was dissolved in

* Sulphadoxine was generously supplied from the Wellcome Research Laboratories, Beckenham, Kent, England, and

* Trimethoprim from Grindstedværket, Aarhus, Denmark. 
$50 \mathrm{ml}$ distilled water added lactic acid $(1 \mathrm{ml}$ lactic acid per $\mathrm{g}$ trimethoprim). The solution of trimethoprim used for the continuous intravenous infusion was diluted with distilled water.

Blood samples were taken at intervals of $30 \mathrm{~min}$. through a plastic cannula (Braunüle $2 \mathrm{R}$ ) placed in the right jugular vein. The bladder was emptied at 30 -min. intervals via a balloon catheter (Rüsch no. 28, $75 \mathrm{ml}$ ). Before the start of the infusion the mammary glands were milked out completely. During the experiment the glands were milked out at intervals of $30 \mathrm{~min}$. In each experiment 5 or 6 blood, urine and milk samples were taken for determination of sulphadoxine, trimethoprim and creatinine. The sampling was started $30 \mathrm{~min}$. after establishment of the continuous intravenous infusion.

Sulphadoxine in blood plasma, urine and milk was measured ad modum Bratton \& Marshall (1939) modified for milk by Rasmussen (1958). Trimethoprim was estimated according to the method of Schwartz et al. (1969).

The protein binding of sulphadoxine and trimethoprim in blood plasma and milk was determined by ultrafiltration by the method of Poulsen (1956). The cellophane membrane used was "Kalle" dialysing tube, diameter $32 \mathrm{~mm}$, pore size $20-80 \AA$, which should permit molecules with a molecular weight up to 5,000 to pass through.

The endogenous creatinine clearance was used to express the glomerular filtration rate. Creatinine was estimated by the method described by Bonsnes \& Taussky (1945).

The $\mathrm{pH}$ of the blood, milk and urine samples was measured immediately after each experiment by means of a potentiometer with glass electrode (Radiometer, Copenhagen) at $37^{\circ} \mathrm{C}$.

The $\mathrm{pK}_{\mathrm{a}}$ value of sulphadoxine is 6.1 (Struller 1968) and of trimethoprim 7.6 (Rasmussen 1970).

Calculations of the theoretical distribution (R) of non-proteinbound drug between milk (M. Ultr.) and plasma (P. Ultr.) were made on the basis of the $\mathrm{pK}_{\mathrm{a}}$ value of the drug and the $\mathrm{pH}$ in blood $\left(\mathrm{pH}_{\mathrm{b}}\right)$ and milk $\left(\mathrm{pH}_{\mathrm{m}}\right)$, by means of the formula (Rasmussen 1958, 1966):

$$
\begin{aligned}
& \mathrm{R}=\frac{\text { M.Ultr. }}{\text { P.Ultr. }}=\frac{1+10^{\left(\mathrm{pH}_{\mathrm{m}}-\mathrm{pK}_{\mathbf{a}}\right)}}{1+10^{\left(\mathrm{pH}_{\mathbf{b}}-\mathrm{pK}_{\mathbf{a}}\right)}} \text { for acids and } \\
& \mathrm{R}=\frac{\text { M.Ultr. }}{\text { P.Ultr. }}=\frac{1+10^{\left(\mathrm{pK}_{\mathbf{a}}-\mathrm{pH}_{\mathrm{m}}\right)}}{1+10^{\left(\mathrm{pK}_{\mathrm{a}}-\mathrm{pH}_{\mathbf{b}}\right)}} \text { for bases. }
\end{aligned}
$$

The statistical calculations were done in accordance to standard methods (Kemp 1955) and the results are given as average \pm s.e.m. The relationships between the renal clearance of each drug, and the concentration of drug, urine $\mathrm{pH}$, urine flow-rate 
were examined by means of correlation matrices and multiple regression analyses (Dixon 1967).

\section{Protein-binding}

\section{RESULTS}

In Tables 1 and 2 are listed the concentrations of sulphadoxine and trimethoprim in plasma and milk and in ultrafiltrates of plasma and milk. The protein-binding of sulphadoxine was highest $(66 \pm 2 \%, \mathrm{n}=6$ ) at concentrations of sulphadoxine in plasma lower than $100 \mathrm{~kg} / \mathrm{ml}$ and lowest $(48 \pm 1 \%, \mathrm{n}=9)$ at concentrations higher than $150 \mu \mathrm{g} / \mathrm{ml}$, this difference is significant $(P<0.05)$. The binding of sulphadoxine to the plasma proteins was not influenced by the presence of trimethoprim. The binding of trimethoprim to plasma proteins was in average $57 \pm$ $2 \%$ independent of the concentration of trimethoprim, and the binding of trimethoprim was not influenced by sulphadoxine in plasma. Both sulphadoxine and trimethoprim were bound to the proteins in milk $4 \pm 2 \%$ and $41 \pm 2 \%$, respectively.

Table 1. The concentration of sulphadoxine in plasma and milk and in ultrafiltrate of plasma and milk.

\begin{tabular}{|c|c|c|c|c|c|c|c|c|c|c|}
\hline \multirow[t]{2}{*}{$\begin{array}{l}\text { Cow } \\
\text { no. }\end{array}$} & \multirow{2}{*}{$\begin{array}{c}\text { Experi- } \\
\text { ment } \\
\text { no. }\end{array}$} & \multirow[t]{2}{*}{$\begin{array}{c}\text { Plasma } \\
\mu \mathrm{g} / \mathrm{ml}\end{array}$} & \multirow[t]{2}{*}{$\begin{array}{l}\text { Milk } \\
\mu \mathrm{g} / \mathrm{ml}\end{array}$} & \multirow[t]{2}{*}{$\begin{array}{l}\text { Ratio } \\
\text { M/P }\end{array}$} & \multicolumn{2}{|c|}{$\begin{array}{c}\text { Ultrafiltrates } \\
\text { of }\end{array}$} & \multirow{2}{*}{$\begin{array}{c}\text { Experi- } \\
\text { mental } \\
\text { ratio } \\
\text { M.Ultr. } \\
\text { P. Litr. }\end{array}$} & \multirow[t]{2}{*}{$\begin{array}{c}\text { Blood } \\
\text { pH }\end{array}$} & \multirow[t]{2}{*}{$\begin{array}{c}\text { Milk } \\
\text { pH }\end{array}$} & \multirow{2}{*}{$\begin{array}{c}\text { Theore- } \\
\text { tical } \\
\text { ratio } \\
\text { M.Ultr. } \\
\text { P.Ultr. }\end{array}$} \\
\hline & & & & & $\begin{array}{c}\text { plasma } \\
\mu \mathrm{g} / \mathrm{ml}\end{array}$ & $\begin{array}{l}\text { milk } \\
\mu \mathrm{g} / \mathrm{ml}\end{array}$ & & & & \\
\hline 3 & 1 & 29 & 2 & 0.1 & - & - & - & 7.50 & 6.80 & 0.2 \\
\hline 2 & 2 & 34 & 6 & 0.2 & - & - & - & 7.55 & 7.15 & 0.4 \\
\hline 2 & 3 & 34 & 5 & 0.2 & 12 & 5 & 0.5 & 7.50 & 7.10 & 0.4 \\
\hline 2 & 4 & 37 & 6 & 0.2 & 12 & 6 & 0.5 & 7.50 & 7.15 & 0.5 \\
\hline 5 & 5 & 43 & 4 & 0.1 & 12 & 4 & 0.4 & 7.45 & 6.95 & 0.3 \\
\hline 4 & 6 & 53 & 7 & 0.1 & 16 & 7 & 0.5 & 7.60 & 7.10 & 0.3 \\
\hline 4 & 7 & 56 & 8 & 0.2 & 13 & 8 & 0.6 & 7.50 & 7.10 & 0.4 \\
\hline 1 & 8 & 82 & 9 & 0.1 & 28 & 9 & 0.3 & 7.45 & 7.00 & 0.3 \\
\hline 2 & 9 & 84 & 19 & 0.2 & 39 & 14 & 0.4 & 7.65 & 7.30 & 0.5 \\
\hline 1 & 10 & 88 & 15 & 0.2 & 32 & 15 & $0 . \tilde{3}$ & 7.50 & 7.05 & 0.4 \\
\hline 3 & 11 & 96 & 14 & 0.2 & 35 & 12 & 0.4 & 7.50 & 7.20 & 0.5 \\
\hline 2 & 12 & 157 & 28 & 0.2 & 87 & 28 & 0.3 & 7.55 & 7.05 & 0.3 \\
\hline 3 & 13 & 218 & 64 & 0.3 & 108 & 63 & 0.6 & 7.45 & 7.20 & 0.6 \\
\hline 5 & 14 & 232 & 74 & 0.3 & 126 & 72 & 0.6 & 7.45 & 7.25 & 0.6 \\
\hline 5 & 15 & 248 & 39 & 0.2 & 132 & 35 & 0.3 & 7.45 & 6.90 & 0.3 \\
\hline 4 & 16 & 254 & 68 & 0.3 & 129 & 65 & 0.5 & 7.45 & 7.15 & 0.5 \\
\hline 4 & 17 & 263 & 63 & 0.2 & 130 & 62 & 0.5 & 7.45 & 7.15 & 0.5 \\
\hline
\end{tabular}

- too low to calculate the ratio. 
Table 2. The concentration of trimethoprim in plasma and milk and in ultrafiltrates of plasma and milk.

\begin{tabular}{|c|c|c|c|c|c|c|c|c|c|c|}
\hline \multirow[t]{2}{*}{$\begin{array}{l}\text { Cow } \\
\text { no. }\end{array}$} & \multirow{2}{*}{$\begin{array}{c}\text { Experi- } \\
\text { ment } \\
\text { no. }\end{array}$} & \multirow[t]{2}{*}{$\begin{array}{c}\text { Plasma } \\
\mu \mathrm{g} / \mathrm{ml}\end{array}$} & \multirow[t]{2}{*}{$\begin{array}{l}\text { Milk } \\
\mu \mathrm{g} / \mathrm{ml}\end{array}$} & \multirow[t]{2}{*}{$\begin{array}{l}\text { Ratio } \\
\mathbf{M} / \mathbf{P}\end{array}$} & \multicolumn{2}{|c|}{$\begin{array}{l}\text { Ultrafiltrates } \\
\text { of }\end{array}$} & \multirow{2}{*}{$\begin{array}{l}\text { Experi- } \\
\text { mental } \\
\text { ratio } \\
\text { M. Lltr. } \\
\text { P. Uiltr. }\end{array}$} & \multirow[t]{2}{*}{$\begin{array}{c}\text { Blood } \\
\text { pH }\end{array}$} & \multirow[t]{2}{*}{$\begin{array}{l}\text { Milk } \\
\text { pH }\end{array}$} & \multirow{2}{*}{$\begin{array}{c}\text { Theore- } \\
\text { tical } \\
\text { ratio } \\
\text { M.Ultr. } \\
\text { P. Ultr. }\end{array}$} \\
\hline & & & & & $\begin{array}{r}\text { plasma } \\
\mu \mathrm{g} / \mathrm{ml}\end{array}$ & $\begin{array}{l}\text { milk } \\
\mu \mathrm{g} / \mathrm{ml}\end{array}$ & & & & \\
\hline 3 & 1 & 0.6 & 1.7 & 3.2 & 0.2 & 1.0 & 5.0 & 7.50 & 6.80 & 3.2 \\
\hline 2 & 18 & 0.6 & 0.9 & 1.4 & 0.3 & 0.6 & 1.9 & 7.55 & 7.20 & 1.7 \\
\hline 2 & 3 & 0.9 & 1.4 & 1.6 & 0.3 & 0.9 & 2.5 & 7.50 & 7.10 & 1.4 \\
\hline 5 & $\overline{5}$ & 0.9 & 1.9 & 2.0 & 0.3 & 1.0 & 3.0 & 7.45 & 6.95 & 2.3 \\
\hline 2 & 2 & 1.2 & 1.3 & 1.1 & 0.6 & 0.9 & 1.5 & 7.55 & 7.15 & 1.8 \\
\hline 3 & 19 & 1.2 & 2.2 & 1.8 & 0.6 & 1.0 & 1.7 & 7.50 & 7.00 & 2.2 \\
\hline 2 & 9 & 1.5 & 1.7 & 1.1 & 0.7 & 0.9 & 1.3 & 7.65 & 7.30 & 1.6 \\
\hline 3 & 11 & 1.6 & 2.8 & 1.8 & 0.7 & 1.5 & 2.1 & $7 . \overline{5} 0$ & 7.20 & 1.6 \\
\hline 1 & 8 & 1.7 & 4.0 & 2.4 & 0.7 & 2.6 & 3.6 & 7.45 & 7.00 & 2.1 \\
\hline 4 & 16 & 1.8 & 2.3 & 1.3 & 0.8 & 1.7 & 2.2 & 7.45 & 7.15 & 1.6 \\
\hline 1 & 10 & 1.9 & 3.7 & 1.9 & 1.0 & $2 . \overline{5}$ & 2.6 & 7.50 & 7.05 & 2.0 \\
\hline 4 & 6 & 2.0 & 4.3 & 2.1 & 0.8 & 2.1 & 2.5 & 7.60 & 7.10 & 1.6 \\
\hline 2 & 12 & 2.1 & 2.6 & 1.2 & 0.6 & 1.4 & 2.5 & 7.55 & 7.05 & 2.1 \\
\hline 5 & 20 & 2.5 & 3.6 & 1.4 & 1.1 & 2.1 & 1.9 & 7.40 & 7.20 & 1.4 \\
\hline 5 & 21 & 3.7 & 4.6 & 1.2 & 1.6 & 2.8 & 1.8 & 7.40 & 7.00 & 1.9 \\
\hline 5 & 14 & 7.8 & 9.3 & 1.2 & 3.7 & 5.1 & 1.4 & 7.45 & 7.25 & 1.3 \\
\hline
\end{tabular}

\section{Mammary excretion}

The mammary excretion of sulphadoxine and trimethoprim was examined in 17 and 16 experiments, respectively. The results in Table 1 show that the concentrations of sulphadoxine were much lower in milk than in plasma (ratio $M / P$ and M.Ultr./ P.Ultr.). The experimentally found ratios between the concentration of non-protein-bound sulphadoxine in milk and plasma (ratio M.Ultr./P.Ultr.) are given in column 8 of Table 1. Furthermore, the $\mathrm{pH}$ of the blood and milk, together with the theoretically calculated ratios between the concentration of non-proteinbound sulphadoxine in ultrafiltrates of milk and plasma, can be seen from the last 3 columns.

The concentrations of trimethoprim in milk were $1.1-3.2$ times higher than in plasma (Table 2, ratio $M / P$ ). The experimentally found ratios between the concentration of non-proteinbound trimethoprim in milk and plasma (M.Ultr./P.Ultr.) are shown in Table 2. They varied from 1.3 to 5.0. The $\mathrm{pH}$ of blood and milk and the theoretically calculated ratio between the con- 
centration of trimethoprim in ultrafiltrates of milk and plasma, can be seen from the last 3 columns.

From Tables 1 and 2 it is seen that an increase in the $\mathrm{pH}$ of milk means an increase in the ratio M.Ultr./P.Ultr. for sulphadoxine and a decrease in the ratio M.Ultr./P.Ultr. for trimethoprim. This is also illustrated in Fig. 1 demonstrating the results obtained in an experiment with nearly constant levels in ultrafiltrate of plasma of sulphadoxine $(14-17 \mu \mathrm{g} / \mathrm{ml})$ and trimethoprim $(0.7-1.0 \mu \mathrm{g} / \mathrm{ml})$ and with rather big variation in $\mathrm{pH}$ of the milk samples during the experimental period. The concentrations of drug in the milk samples varied appreciably, but the concentrations of sulphadoxine were in all cases lower than in plasma, while the concentrations of trimethoprim in milk in all cases were higher than in plasma.

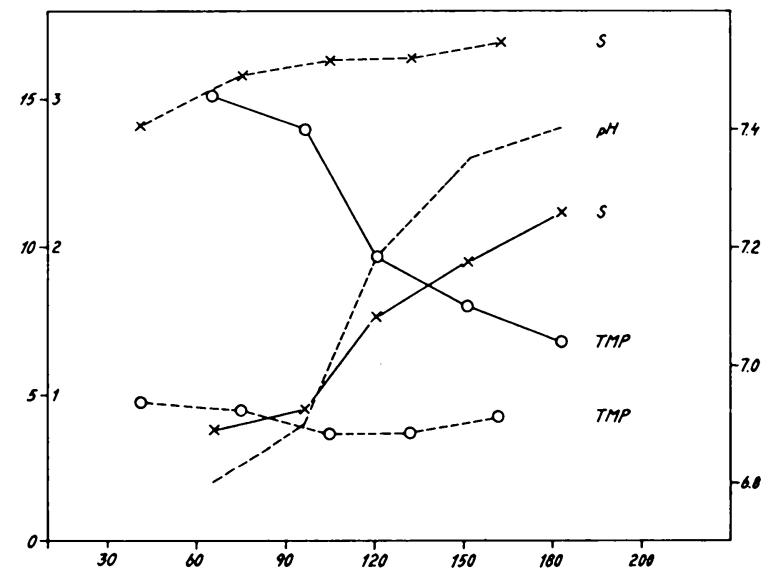

Figure 1. Concentrations of non-protein-bound sulphadoxine and non-protein-bound trimethoprim in plasma and milk at different $\mathrm{pH}$ values in milk.

Ordinate on the left: Concentration of sulphadoxine $(0-15 \mu \mathrm{g} / \mathrm{ml})$ and of trimethoprim $(0-3 \mu \mathrm{g} / \mathrm{ml})$.

Ordinate on the right: $\mathrm{pH}$ of the milk.

Abscissa: Time in minutes.

$x$-... $x$ : Sulphadoxine in ultrafiltrate of plasma.

$x-x$ : Sulphadoxine in ultrafiltrate of milk.

o - ... o: Trimethoprim in ultrafiltrate of plasma.

o- o: Trimethoprim in ultrafiltrate of milk.

....... pH of the milk. 


\section{Renal clearance}

Clearance of endogenous creatinine, sulphadoxine and trimethoprim was determined in 21, 17 and 16 experiments, respectively, and the average results of each experiment are shown in Table 3.

S u l p h a d ox in e

From Table 3 it is seen that the plasma clearances of sulphadoxine and even non-protein-bound sulphadoxine (Clears.ultr.) were much lower than the clearance of endogenous creatinine (ratio columns 9 and 10 ).

By means of multiple regression analysis 2 regression equations have been calculated. Both equations give the influence of the concentration of non-protein-bound sulphadoxine ( $\left.\mathrm{C}_{\mathbf{s} \text {.ultr. }}\right)$, the urine $\mathrm{pH}$ and the urine flow rate $(\mathrm{V})$ on the renal clearance of sulphadoxine in comparison to the clearance of creatinine. The regression equations are

Clearance ratio $=\frac{\text { Clear }_{\text {S.ultr. }}}{\text { Clear }_{\text {Cr. }}}=$

$-1.74-0.00012 \mathrm{C}_{\text {s.ultr. }}+0.25 \mathrm{pH}+0.023 \mathrm{~V}$

and

log. clearance ratio $=\log . \frac{\text { Clear } \text { s.ultr. }}{\text { Clear } \text { Cr. }}=$

$-6.29-0.00062 \mathrm{C}_{\text {S. ultr. }}+0.70 \mathrm{pH}+0.044 \mathrm{~V}$

Correlation analysis showed significant correlation between clearance ratio and both the concentration of non-protein-bound sulphadoxine $\left(\mathrm{C}_{\text {s.ultr. }}\right)$ and the $\mathrm{pH}$ of the urine, while clearance ratio and the urine flow rate were not significantly correlated (Table 4 ). The regression equations show that the $\mathrm{pH}$ of the urine is by far the most important of the above mentioned factors which influence the renal clearance of sulphadoxine.

The first regression equation (1) explains about $55 \%$ of the variations in the clearance ratio while the second one (2) explains about $73 \%$ of this variation.

The found relation between the renal excretion of non-protein-bound sulphadoxine and the $\mathrm{pH}$ of the urine is further demonstrated in Fig. 2 giving the results of 5 experiments on 2 


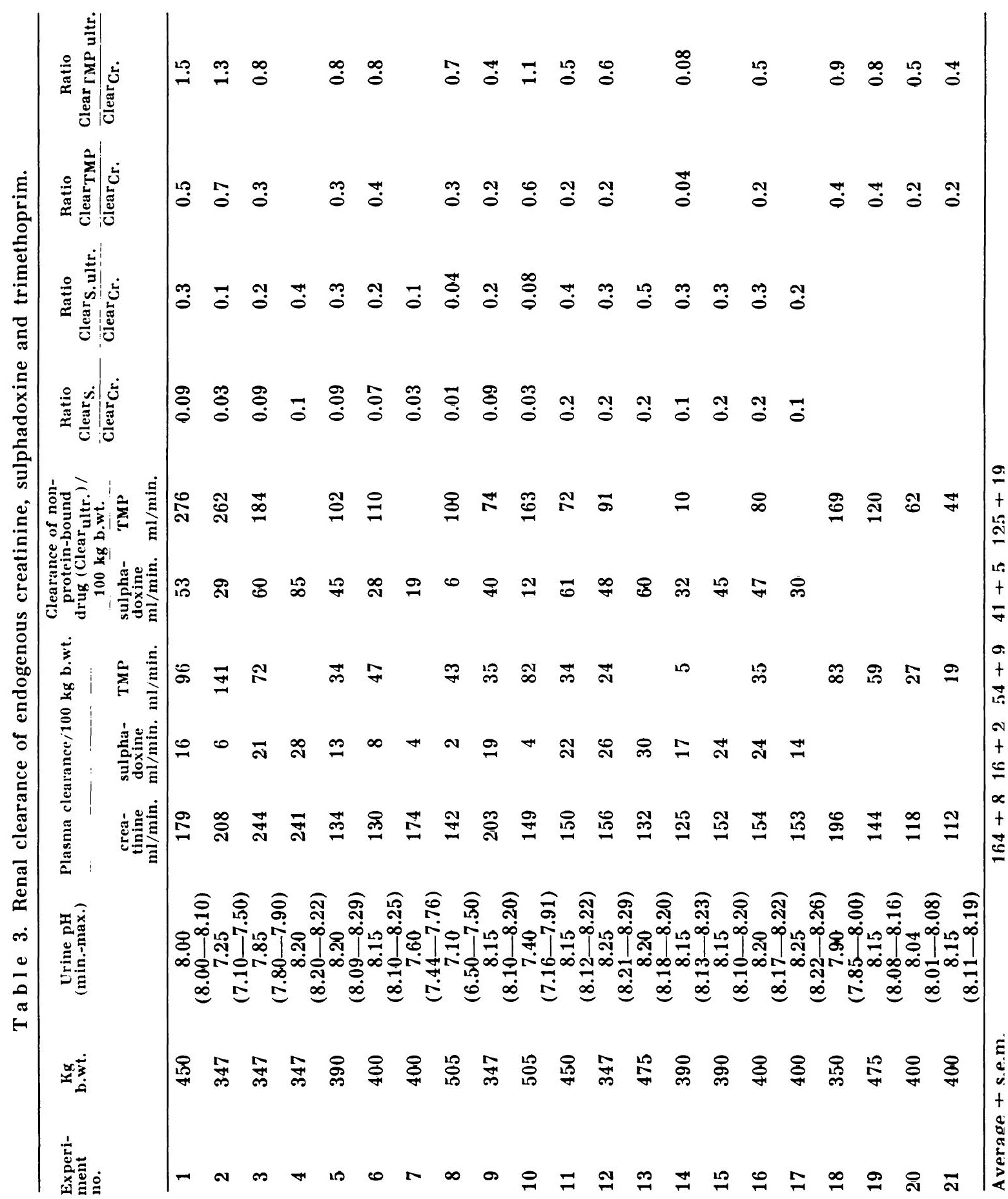


T a b le 4. Correlation coefficients ( $r$ ) between variables i.e. clearance ratio and the concentration of non-protein-bound drug in blood plasma $\left(\mathrm{C}_{\text {s.ultr. }}\right.$ and $\mathrm{C}_{\mathrm{TMP}}$ ultr. $)$, the $\mathrm{pH}$ of the urine and the urine flow rate $(V)$.

\begin{tabular}{|c|c|c|c|c|}
\hline \multicolumn{3}{|c|}{ Variables } & \multirow{2}{*}{$\begin{array}{r}r \\
0.26 \\
0.71 \\
-0.02\end{array}$} & \multirow{2}{*}{$\begin{array}{c}\mathrm{P} \\
0.01<\mathrm{P}<0.05 \\
<\begin{array}{c}0.001 \\
\text { n.s. }\end{array}\end{array}$} \\
\hline $\begin{array}{l}\text { Clear } \\
\text { Clear }\end{array}$ & S.ultr. & $\begin{array}{l}\mathrm{C}_{\text {S. ultr. }} \\
\mathrm{pH} \\
\mathrm{V}\end{array}$ & & \\
\hline Log. & $\begin{array}{l}\text { Clear s.ultr. } \\
\text { Clear } \mathrm{Cr} .\end{array}$ & $\begin{array}{l}\mathrm{C}_{\mathrm{S} . \text { ultr. }} \\
\mathrm{pH} \\
\mathrm{V}\end{array}$ & $\begin{array}{r}0.27 \\
0.83 \\
-0.08\end{array}$ & $\begin{array}{c}0.01<\mathrm{P}<0.05 \\
<0.001 \\
\text { n.s. }\end{array}$ \\
\hline$\frac{\text { Clear }}{\text { Clear }}$ & $\frac{\text { TMP ultr. }}{\text { Cr. }}$ & $\begin{array}{l}\mathrm{C}_{\mathrm{TMP}} \text { ultr. } \\
\mathrm{pH} \\
\mathrm{V}\end{array}$ & $\begin{array}{r}-0.55 \\
-0.42 \\
0.42\end{array}$ & $\begin{array}{l}<0.001 \\
<0.001 \\
<0.001\end{array}$ \\
\hline Log. & $\frac{\text { Clear }}{\text { Clear }}$ Cr. & $\begin{array}{l}\mathrm{C}_{\mathrm{TMP}} \text { ultr. } \\
\mathrm{pH} \\
\mathrm{V}\end{array}$ & $\begin{array}{r}-0.83 \\
-0.38 \\
0.36\end{array}$ & $\begin{aligned}<0.001 \\
<0.001 \\
0.001<\mathrm{P}<0.01\end{aligned}$ \\
\hline
\end{tabular}

cows excreting urine with $\mathrm{pH}$ between 7.1 and 8.3 . It will be seen that the excretion of sulphadoxine was highest in relation to the excretion of endogenous creatinine when the $\mathrm{pH}$ of the urine was high.

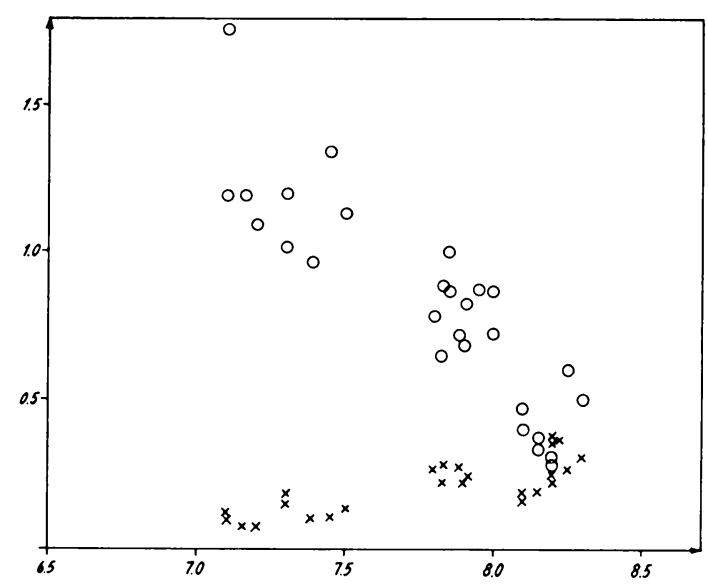

Figure 2. Ratio of the clearance of non-protein-bound drug to endogenous creatinine clearance in relation to urine $\mathrm{pH}$.

Ordinate: Clear of non-protein-bound drug/Clear of creatinine.

Abscissa: Urine pH.

$\mathrm{x}$ Sulphadoxine.

o Trimethoprim. 
As mentioned above the correlation analysis showed that the clearance ratio and the plasma concentration of non-proteinbound sulphadoxine $\left(\mathrm{C}_{\mathrm{S} \text {. ultr. }}\right)$ were significantly correlated. The regression equations show, however, that the clearance ratio was only to a very small degree influenced by this factor in the concentration interval oblained in these experiments. This is further demonstrated in Fig. 3 giving the results from experiments with nearly constant $\mathrm{pH}$ in the urine ( $\mathrm{pH} 8.0-8.3)$.



Figure 3. Ratio of the clearance of non-protein-bound drug to endogenous creatinine clearance in relation to the concentration of non-protein-bound sulphadoxine and non-protein-bound trimethoprim in plasma.

Ordinate: Clear of non-protein-bound drug/Clear of creatinine.

Abscissa above: Conc. of non-protein-bound sulphadoxine in plasma. Abscissa below: Conc. of non-protein-bound trimethoprim in plasma. $x$ Sulphadoxine.

o Trimethoprim.

Trimeth oprim

The clearance of trimethoprim from plasma was also lower than the clearance of creatinine, while the clearance of non-protein-bound trimethoprim varied from 8 to $150 \%$ of creatinine clearance (last column in Table 3 ).

As in the case of sulphadoxine, 2 regression equations were calculated as follows 
Clearance ratio $=\frac{\text { Clear }_{\mathrm{TMP} \text { ultr. }}}{\text { Clear }_{\mathrm{Cr}} \text {. }}=$

$2.89 \multimap 0.24 \mathrm{C}_{\text {TMP ultr. }}-0.26 \mathrm{pH}+0.102 \mathrm{~V}$

and

log. clearance ratio $=\log . \frac{\text { Clear }}{\text { Clear }} \frac{\mathrm{TMP} \text { ultr. }}{\mathrm{Cr} .}=$

$1.32-0.29 \mathrm{C}_{\text {TMP ultr. }}-0.17 \mathrm{pH}+0.06 \mathrm{~V}$

Correlation analysis showed that the clearance ratio (Table 4) was significantly correlated with the concentration of nonprotein-bound trimethoprim $\left(\mathrm{C}_{\mathrm{TMP}}\right.$ ultr. $)$, the $\mathrm{pH}$ of urine and the urine flow rate $(\mathrm{V})$.

The first equation (3) explains about $49 \%$ while the second one (4) explains more than $81 \%$ of the observed variations in the clearance ratio. Variations in the concentration of non-protein-bound trimethoprim influence the clearance ratio much more than urine $\mathrm{pH}$, and the variations in the urine flow rate are of less importance. The excretion of trimethoprim in relation to clearance of creatinine diminishes when the concentration of non-protein-bound trimethoprim in plasma increases (Fig. 3). In the experiments included in this figure, the $\mathrm{pH}$ of the urine was constant (between 8.0 and 8.3) and has not influenced the renal excretion of trimethoprim. The influence of variations in urine $\mathrm{pH}$ on the renal excretion of trimethoprim is further demonstrated in Fig. 2, which reveals that the ratio ultrafiltrate clearance of trimethoprim/filtration clearance was lowest when the $\mathrm{pH}$ of the urine was high.

\section{DISCUSSION}

The binding of sulphadoxine to the plasma proteins in cows is $66 \%$ at plasma levels below $100 \mu \mathrm{g} / \mathrm{ml}$ and $48 \%$ at plasma levels above $150 \mu \mathrm{g} / \mathrm{ml}$. A similar relationship between the binding of sulphadoxine to the proteins in plasma and the plasma level of sulphadoxine is seen in goats (Jørgensen \& Rasmussen 1972). The binding of trimethoprim to the plasma proteins in cows is a little higher than in goats (Rasmussen 1970) and is of the same order as found by Craig \& Kunin (1973) in humans. However, Bushby \& Hitchings (1968) and Schwartz \& Ziegler 
(1969) found that only between 30 and $46 \%$ of trimethoprim was bound to proteins in human plasma. The binding of sulphadoxine to plasma proteins is not influenced by trimethoprim and vice versa and this resembles Schwartz \& Ziegler's finding with trimethoprim and sulphamethoxazole in human plasma.

The binding of sulphadoxine to milk proteins in cows is lower $(4 \%)$ than in goats $(16 \%)$ (Jørgensen 1972), while the binding of trimethoprim to milk proteins in cows $(42 \%)$ is higher than in goats (12\%) (Rasmussen 1970).

According to the finding that only the non-protein-bound and unionized fraction of drugs can diffuse into milk and establish equilibrium across the mammary gland epithelium (Rasmussen 1958, 1966, 1971, 1973) sulphadoxine should give lower concentrations in milk than in plasma. In accordance to this the results in Table 1 show that the concentrations in milk were constantly lower than in plasma. During equilibrium conditions the experimentally found distribution (exp. M.Ultr./P.Ultr.) and the calculated distribution of sulphadoxine between the ultrafiltrates of milk and plasma show good agreement. Similar results were obtained with sulphadoxine in goats (Jørgensen).

The concentrations of the base trimethoprim in milk should be equal to or higher than in plasma (Table 2). The experimentally found distribution (exp. M.Ultr./P.Ultr.) and the calculated distribution of trimethoprim between ultrafiltrates of milk and plasma prove this hypothesis, which also is confirmed in experiments on goats (Rasmussen 1970). The fact that the unionized fraction of sulphadoxine and trimethoprim is important for concentrations of drug in milk compared with the concentration in plasma is further strengthened by the results shown in Fig. 1. A similar dependence between the $\mathrm{pH}$ of milk and the concentration of drug in milk is seen for ather partly ionized drugs i. e. sulphadiazine (Rasmussen 1958, 1966), penicillin and erythromycin (Rasmussen 1959) and lincomycin (Gyrd-Hansen \& Rasmussen 1967, Ziv \& Sulman 1973 b).

The renal clearance of endogenous creatinine in cows express the glomerular filtration (Poulsen 1956). The renal clearance of endogenous creatinine in these experiments was found to be $164 \pm 8 \mathrm{ml} / \mathrm{min} . / 100 \mathrm{~kg} \mathrm{~b}$. wt. (Table 3 ) and resembles the results $(168 \mathrm{ml} / \mathrm{min} . / 100 \mathrm{~kg}$ ) obtained by Poulsen.

As the protein-bound fraction of drugs cannot filter through the glomeruli of the kidneys the excretory mechanism must be 
determined on the basis of the comparison between glomerular filtration rate and the clearance of non-protein-bound sulphadoxine and trimethoprim. The clearance of non-protein-bound sulphadoxine was always much lower than the clearance of creatinine, which indicates in addition to filtration, a high degree of back-diffusion of sulphadoxine dependent on the $\mathrm{pH}$ of the urine (Fig. 2, Table 4). This back-diffusion is most pronounced in urine of low $\mathrm{pH}$ when sulphadoxine is more unionized (diffusible) than in urine of high $\mathrm{pH}$. A similar influence of urine $\mathrm{pH}$ on the back-diffusion of sulphadoxine is seen in goats ( $J \phi r$ gensen \& Rasmussen) and in humans (Portwich \& Büttner 1964). The clearance of sulphadoxine is only to a small degree dependent on the variations in the concentrations of non-protein-bound sulphadoxine in plasma (equations 1 and 2). Therefore it is not possible from these experiments to decide whether an active tubular secretion is involved in the renal handling of sulphadoxine as seen in goats (Jørgensen \& Rasmussen) and in humans (Reber et al. 1964, Portwich \& Büttner 1964). However, the high degree of back-diffusion might shadow an active secretion.

The clearance of non-protein-bound trimethoprim varies from 8 to $150 \%$ of the clearance of creatinine. This indicates that, in addition to filtration, both active tubular secretion and backdiffusion are involved in the renal handling of trimethoprim corresponding to observations in goats (Rasmussen 1970) and in humans (Sharpstone 1969, Bergan \& Brodwall 1972).

The variations in the clearance of trimethoprim are related to the concentration of trimethoprim in plasma and the $\mathrm{pH}$ of the urine. High concentrations diminish (Fig. 3 and Table 4) drastically the renal excretion of trimethoprim, and these results indicate selfdepression and support the assumption that active tubular secretion is involved in the renal handling of trimethoprim.

The clearance of non-protein-bound trimethoprim is higher at low $\mathrm{pH}$ than at high $\mathrm{pH}$ in the urine (Fig. 2, Table 4). At high $\mathrm{pH}$ of the urine trimethoprim is more unionized (diffusible) than at low $\mathrm{pH}$ and back-diffusion is pronounced as also seen in goats (Rasmussen 1970) and in humans (Sharpstone, Bergan \& Brodwall, Craig \& Kunin). 


\section{REFERENCES}

Bergan, T. \& E. K. Brodwall: Kidney transport in man of sulfamethoxazole and trimethoprim. Chemotherapy (Basel) 1972, 17, $320-333$.

Beyer, K. H., L. Peters, E. A. Patch \& H. F. Russo: The renal elimination of sulphamerazine, sulphamethazine, sulphadiazine and sulphathiazole by the dog. J. Pharmacol. exp. Ther. 1944, 82, $239-246$.

Bonsnes, R. W. \& H. H. Taussky: On the colorimetric determination of creatinine by the Jaffe reaction. J. biol. Chem. 1945, 158, $581-591$.

Bratton, A. C. \& E. K. Marshall: A new coupling component for sulphanilamide determination. J. biol. Chem. 1939, 128, 537-550.

Bushby, S. R. M. \& G. H. Hitchings: Trimethoprim, a sulphonamide potentiator. Brit. J. Pharmacol. 1968, 33, 72-90.

Craig, W. A. \& C. M. Kunin: Trimethoprim-sulphamethoxazole: Pharmacodynamic effects of urinary $\mathrm{pH}$ and impaired renal function. Ann. intern. Med. 1973, 78, 491-497.

Dalgaard-Mikkelsen, Sv.: On the renal excretion of salicylate. Acta pharmacol. (Kbh.) 1951, 7, 243-258.

Dalgaard-Mikkelsen, Sv. \& E. Poulsen: Renal excretion of sulphathiazole and sulphadimidine in pigs. Acta pharmacol. (Kbh.) 1956, 12, $233-239$.

Dixon, W. J.: BMD. Biomedical computer programs. University of California Press 1967, pp. 258-275.

Gyrd-Hansen, N. \& Folke Rasmussen: Renal og mammær ekskretion af lincomycin hos køer. (Renal and mammary excretion of lincomycin in cows). Nord. Vet.-Med. 1967, 19, 11-16.

Jørgensen, Sigrid Tue: Mammær ekskretion hos geder af sulfadoxin og sulfamethoxazol sammenlignet med sulfanilamid og sulfadimidin. (Mammary excretion in goats of sulphadoxine and sulphamethoxazole compared with sulphanilamide and sulphadimidine). Nord. Vet.-Med. 1972, 2/, 1-10.

Jørgensen, Sigrid Tue \& Folke Rasmussen: Renal ekskretion af sulfanilamid, sulfadimidin, sulfadoxin og sulfamethoxazol hos geder. (Renal excretion of sulphanilamide, sulphadimidine, sulphadoxine and sulphamethoxazole in goats). Nord. Vet.-Med. 1972, 24, 601-611.

Kemp, T.: Statistik for medicinere. (Statistics for physicians). Munksgaard, København 1955.

Portwich, F. \& H. Büttner: Zur Pharmakokinetik eines langwirkenden Sulfonamids (4-Sulfanilamido-5,6-dimethoxypyrimidin) beim gesunden Menschen. (Pharmacokinetic studies with 4-sulphanilamido-5,6-dimethoxypyrimidine in healthy humans). Klin. Wschr. 1964, 42, 740-744.

Poulsen, E.: Renale clearanceunders $\emptyset$ gelser hos køer. (Renal clearance in cows). Thesis, C. Fr. Mortensen, København 1956. 
Rasmussen, Folke: Mammary excretion of sulphonamides. Acta phar. macol. (Kbh.) 1958, 15, 139-148.

Rasmussen, Folke: Mammary excretion of benzylpenicillin, erythromycin, and penethamate hydriodide. Acta pharmacol. (Kbh.) $1959,16,194-200$.

Rasmussen, Folke: Studies on the mammary excretion and absorption of drugs. Thesis, C. Fr. Mortensen, Copenhagen 1966.

Rasmussen, Folke: Renal and mammary excretion of trimethoprim in goats. Vet. Rec. 1970, 87, 14-18.

Rasmussen, Folke: Excretion of drugs by milk. In B. B. Brodie \& J. Gillette: Handbook of Experimental Pharmacology. Vol. 28-1, Springer Verlag, Berlin 1971.

Rasmussen, Folke: The mechanism of drug secretion into milk. In C. Galli, G. Jacini \& A. Pecile: Dietary Lipids and Postnatal Development. Raven Press, New York 1973.

Reber, H., G. Rutishauser \& H. Thölen: Clearance-Untersuchungen am Menschen mit Sulfamethoxazol und Sulforthodimethoxin. (Renal clearance of sulphamethoxazole and sulphorthodimethoxine in humans). III Int. Congr. Chemotherapy (July 1963), 1964, 648653.

Schwartz, D. E. \& W. H. Ziegler: Assay and pharmacokinetics of trimethoprim in man and animals. Postgrad. med. J. 1969, 45, suppl., $32-37$.

Schwartz, D. E., B. A. Koechlin \& R. E. Weinfeld: Spectrofluorimetric method for the determination of trimethoprim in body fluids. Chemotherapy (Basel) 1969, 14, suppl., 22-29.

Sisodia, C. S. \& C. M. Stowe: The mechanism of drug secretion into bovine milk. Ann. N. Y. Acad. Sci. 1964, 111, 650-661.

Sharpstone, P.: The renal handling of trimethoprim and sulphamethoxazole in man. Postgrad. med. J. 1969, 45, suppl., 38-42.

Stowe, C. M. \& G. L. Plaa: Extrarenal excretion of drugs and chemicals. Ann. Rev. Pharmacol. 1968, 8, 337--356.

Struller, Th.: Progress in sulfonamide research. Fortschr. Arzneimittelforsch. 1968, 12, 390-451.

Ziv, G. \& R. Risenberg-Tirer: The concentration of several antibiotics in ovine blood and milk following intramuscular injection. Rech. vétér. $1969,2,45-57$.

Ziv, G. \& F. G. Sulman: Serum and milk concentrations of spectinomycin and tylosin in cows and ewes. Amer. J. vet. Res. 1973 a, $34,329-333$.

Ziv, G. \& F. G. Sulman: Penetration of lincomycin and clindamycin into milk in ewes. Brit. vet. J. $1973 \mathrm{~b}, 129,83-91$.

\section{SAMMENDRAG}

Mammær og renal ekskretion af sulfadoxin og trimethoprim hos køer.

I 21 fors $\emptyset \mathrm{g}$ på normale, ikke drægtige køer er der ved intravenøs infusion af sulfadoxin og trimethoprim opretholdt konstante koncentrationer af disse lægemidler. Forsøgene viser, at både sulfadoxin og 
trimethoprim bindes til proteinerne i blodplasma og mælk. Det fremgår endvidere af forsøgene, at sulfadoxin, som er en syre, udskilles i mælken i koncentrationer, der er lavere end i blodplasma, mens trimethoprim, som er en base, udskilles i mælken i koncentrationer, der er højere end i blodplasma. De opnáede resultater er i overensstemmelse med teorien om, at lægemidler udskilles med mælken ved passiv diffusion.

Den renale udskillelse af sulfadoxin og trimethoprim involverer glomerulær filtration og tilbagediffusion. Hertil kommer, at trimethoprim tillige udskilles ved aktiv tubulær sekretion. Såvel den mammære som den renale ekskretion af sulfadoxin og trimethoprim er påvirkelig af $\mathrm{pH}$ i mælk og urin. Forsøgene har vist, at det er den ikke-ioniserede og ikke-proteinbundne fraktion af lægemidler, der diffunderer gennem biologiske membraner.

(Received January 15, 1974).

Reprints may be requested from: Folke Rasmussen, Department of Pharmacology and Toxicology, Royal Veterinary and Agricultural University, DK-1870 Copenhagen V, Denmark. 